\title{
Imagine, feel "there", and flow! Immersive experiences on m-Facebook, and their affective and behavioural effects
}

\author{
Inma Rodríguez-Ardura and Antoni Meseguer-Artola \\ Faculty of Economics and Business, Universitat Oberta de Catalunya, \\ Barcelona, Spain
}

Imagine, feel "there", and flow!

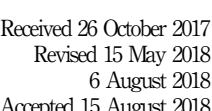

Accepted 15 August 2018

\begin{abstract}
Purpose - Mobile Facebook (m-Facebook) creates many business opportunities for brands and firms while increasingly drawing interest in scientific literature. However, research is scarce on the immersive experiences prompted by m-Facebook, and how these experiences facilitate users' engagement, their positive attitude towards Facebook and their continued use of it. The paper aims to discuss these issues.

Design/methodology/approach - This paper theoretically and empirically analyses m-Facebook users' immersive experiences, along with their affective and behavioural effects.

Findings - The results reveal the important role of imagery, presence and flow in the context of $\mathrm{m}$-Facebook; the interplay between these three immersive phenomena; and the influence the user's optimum stimulation level has on them.

Originality/value - The investigation offers a foundation for understanding users' immersive experiences on m-Facebook, and informs practitioners who aim to enhance users' engagement with, attitude towards, and continued use of $\mathrm{m}$-Facebook content.
\end{abstract}

Keywords OSL, Imagery, Presence, Flow, Engagement, Social networking site, Facebook,

Structural equation modelling

Paper type Research paper

\section{Introduction}

Facebook, for the most part, is used over mobile technologies (see Goggin, 2014). As of March 2017, mobile Facebook (m-Facebook) had a monthly average of approximately 1.784bn active users worldwide (Facebook, 2017), meaning that this mobile social networking site (MSNS) accounted for roughly 50 per cent of all internet users in the world (Internet Live Stats, 2017). The rise of $\mathrm{m}$-Facebook has been accompanied by a corresponding increase in the phenomenal opportunities it offers to practitioners. Through $\mathrm{m}$-Facebook groups, pages and customer reviews, brands and organisations have found a worthwhile way to build and cultivate profitable links with users - from more conventional, yet highly targeted, ads, to content that is attractive and interesting to the user's eye, brand communities and novel modes of ubiquitous social shopping.

At the same time, m-Facebook has become an important issue for theory-driven empirical research. As users' immersive subjective experiences have a potentially strong role in explaining their attitudes and behaviours (Bilgihan et al., 2016; Lin and Lu, 2011; Shin, 2018), the study of m-Facebookers' immersive experiences can give insight into

(C) Inma Rodríguez-Ardura and Antoni Meseguer-Artola. Published by Emerald Publishing Limited. This article is published under the Creative Commons Attribution (CC BY 4.0) licence. Anyone may reproduce, distribute, translate and create derivative works of this article (for both commercial and non-commercial purposes), subject to full attribution to the original publication and authors. The full terms of this licence may be seen at http://creativecommons.org/licences/by/4.0/legalcode

This work was partly supported by the Spanish Government, under Grant No. ECO2014-53837-R, and by the Universitat Oberta de Catalunya (IN3-UOC Resident Researchers Programme 2013).

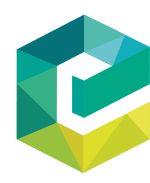

Information Technology \& People Vol. 32 No. 4, 2019 pp. $921-947$

Emerald Publishing Limited 0959-3845 DOI 10.1108/ITP-10-2017-0358 
and lead to a better understanding of online behaviour, simultaneously offering a range of business opportunities for those brands and organisations that want to be easily accessible to consumers anytime and anywhere.

Interestingly, $\mathrm{m}$-Facebook is capable of prompting immersive experiences in its users (Sashittal et al., 2012; Schulze et al., 2014). When using m-Facebook, users plunge into an entertaining and highly engrossing environment, one that allows them to discover what is happening around them, share stories and life experiences with their personal social networks, and express and feel better about themselves (Kim and Lee, 2011; Li et al., 2015). At the psychological, subjective level, Facebookers' experiences can be particularly enthraling. This is because the exploration of and interaction within the medium can unleash positive inner mechanisms (e.g. Alba and Williams, 2013). On a hedonic platform such as m-Facebook (Yang and Lin, 2014), users are more likely to feel comfortable seeking out and discovering new interaction opportunities (Anderson et al., 2012; Gu et al., 2016), employing mental imagery to picture stories and events presented in the medium and imagining their outcomes (Overmars and Poels, 2015; Rodríguez-Ardura and Martínez-López, 2014). Also, they might feel virtually present in the environment or the events depicted on m-Facebook (Makransky et al., 2017; Mennecke et al., 2011), becoming so absorbed on the actions happening online that they might very well disengage and withdraw from their immediate surroundings and go through cognitive episodes of flow (Bachen et al., 2016; Kwak et al., 2014; Pelet et al., 2017).

However, so far, the literature has not shown a great deal of interest in users' immersive experiences on $\mathrm{m}$-Facebook per se (Goggin, 2014). Research has mainly focused on studying the effectiveness of brands' communication initiatives on m-Facebook (e.g. Barreto, 2013; Duffett, 2015; Sanz-Blas et al., 2017); the privacy and risks perceived on m-Facebook (e.g. Błachnio et al., 2016; Wang et al., 2016); the usage and gratifications of m-Facebook (e.g. Chaouali, 2016; Ha et al., 2015; Lin et al., 2017); and the influence wielded by m-Facebookers' personal social networks (e.g. Kwak et al., 2014; Lin et al., 2017; Seo et al., 2016). Furthermore, research into immersive experiences in the broader area of online media has mostly centred on non-hedonic, non-entertaining focal contexts (e.g. Bilgihan et al., 2016; Kumar and Kashyap, 2018; Liu et al., 2018; McLean and Wilson, 2016). Also, the existing body of knowledge of immersive experiences is limited by the fact that most previous studies have only examined a particular sort of immersive experiences, either feelings of being present in the online environment (e.g. Cummings and Bailenson, 2016; Vonkeman et al., 2017) or episodes of flow online (e.g. Kaur, Dhir and Rajala, 2016; Kaur, Dhir, Chen and Rajala, 2016; Liu et al., 2016), and, it is important to note, they have disregarded the psychological experiences of imagery. Even though the knowledge being accumulated in the aforementioned areas provides a good starting point from which to study m-Facebookers' immersive experiences, there is still much to learn about the interplay of these internal, underlying mechanisms and how this explains an individual's feelings and behaviour on $\mathrm{m}$-Facebook.

Therefore, the main purpose of this paper is to expand the thus far limited amount of knowledge of the aggregate of users' immersive experiences on m-Facebook. With this goal in mind, we examine three distinct immersive phenomena, all potentially raised by the individual's use of m-Facebook: imagery, presence feelings and absorption episodes of flow. We model and test the interplay between these three immersive experiences, and we further study their impact on the m-Facebooker's engagement, attitude and continuance behaviour.

The following sections of the paper present the background on the concept of users' immersive experiences, discuss the theoretical foundations for the proposed model and describe the research design used in this study. A report of the findings from a survey of $\mathrm{m}$-Facebookers is then given. The paper concludes with a discussion of the contributions, practical implications and limitations of the study and potential avenues for further research. 


\section{Theoretical framework}

\subsection{Users' immersive experiences}

Immersive experiences have been conceived as internal and subjective episodes brought about by the user's interaction with, and exploration of, the brand's online value proposition (Lemon and Verhoef, 2016; McLean and Wilson, 2016; Shin and Biocca, 2018). In synchrony with the service-dominant logic of marketing (Vargo and Lusch, 2004, 2016), it has been argued that customers' experiences are co-created by organisations and users, and result from the interplay between the user's objectives and the brand's value proposition (Lemke et al., 2010; Lemon and Verhoef, 2016). We use the expression "user immersive experience" rather than "customer experience" to mean the user's holistic, inner mechanisms to assign meaning and generate a response to online value propositions.

There are three characteristics that have been most frequently suggested as constitutive of users' immersive experiences (see e.g. Lemon and Verhoef, 2016; Meyer and Schwager, 2007; Rose et al., 2012). First, immersive experiences are highly personal, insofar as they are based on the individual's processing of the incoming sensory data from the brand's value proposition (McLean and Wilson, 2016; Petermans et al., 2013). Second, immersive experiences emerge from the interactions between the user and the value proposition (Bolton et al., 2014; Rose et al., 2012). And third, they generate positive effects in the form of the user's emotional engagement with the value proposition and his or her affective and behavioural responses (Brodie et al., 2011; Gentile et al., 2007; Kumar and Reinartz, 2016).

A user's immersive experiences, brought about through exploration and interaction within $\mathrm{m}$-Facebook, are particularly compelling. Literature on hedonic consumption (Alba and Williams, 2013; Hirschman and Holbrook, 1982; Holbrook and Hirschman, 1982; Wu and Holsapple, 2014) gives theoretical grounds for understanding why and how m-Facebook can captivate users to such an extent. The use of a hedonic medium like m-Facebook arouses sensory stimuli (Pöyry et al., 2013; Yang and Lin, 2014), which in turn trigger imagery and other positive psychological mechanisms (Hirschman and Holbrook, 1982; Holbrook and Hirschman, 1982; Wu and Holsapple, 2014). When utilising a hedonic medium, the user can feel free to interact with and seek out new sensations (Gu et al., 2016; McDaniel et al., 2001). He or she might turn to imagery to picture the characters and events mentioned in the medium, involve themselves in projective fantasies or construct augmented reality (Hirschman, 1983; Overmars and Poels, 2015; Rodríguez-Ardura and Martínez-López, 2014). In addition to this, users can become so involved in the hedonic activities occurring online that they feel they have been "placed" in an alternative realm, different from their surrounding physical environment (Cheung et al., 2011; Makransky et al., 2017; Mennecke et al., 2011), becoming totally absorbed in the ongoing online activity (Bachen et al., 2016; Kaur, Dhir and Rajala, 2016; Kaur, Dhir, Chen and Rajala, 2016; Kwak et al., 2014; Pelet et al., 2017).

We aim to examine the nature of these immersive, hedonic experiences within the context of m-Facebook usage. To achieve this goal, the ideal scenario would be to conceive the $\mathrm{m}$-Facebooker's experience as a unique, composite construct and consider the experiential facets that are its core dimensions. However, there is no a priori basis for proceeding in such a way because, unlike with utilitarian online consumption, there is very little accumulated knowledge on hedonic behaviour online (Ben-Ur et al., 2015; Martínez-López et al., 2014). To the best of our knowledge, only Rose et al.'s (2012) study delved into online user experiences as holistic gestalts. But these authors exclusively focused on online non-hedonic contexts, so the operationalised construct of user experience they built is based on the more abundant knowledge held on online utilitarian consumption. This lack of previous knowledge does not allow a workable construct of an m-Facebook user's experience to be properly designed, and thus its dimensions would be speculative. Therefore, here we examine the interplay of three distinct immersive experiences (imagery, presence, flow). 
ITP

32,4

924

Their substantive role in hedonic usage of social networking sites (SNSs), mobile and new media has been pointed out by previous studies (Huang, 2012; Kwak et al., 2014; Pelet et al., 2017; Rodríguez-Ardura and Martínez-López, 2014).

\subsection{The personality trait of OSL}

Optimum stimulation level (OSL) has been suggested as being a key personality construct in hedonic consumption situations (Fiore et al., 2005; Helm and Landschulze, 2009; Mahatanankoon, 2007). This is because OSL is deemed to influence the extent to which individuals become involved in novel, non-functional and exploratory behaviours "just for the sake of such experiences" (Zuckerman, 1979, p. 10). OSL theorists argue that each individual is intrinsically motivated to obtain a specific desired level of stimulation (Hebb, 1955; Leuba, 1955; Raju, 1980; Steenkamp and Baumgartner, 1992), the so-called optimum stimulation. And this stimulation can be achieved either from the external environment or via inner mechanisms (Steenkamp and Baumgartner, 1992).

According to OSL theory, people with high-OSL scores are more likely to seek high levels of activation or arousal, while showing a greater aversion to boredom (Helm and Landschulze, 2009; Pizam et al., 2004; Steenkamp and Burgess, 2002). They are eager to expose themselves to new and positive stimuli and situations, insofar as this allows them to fulfil their need for excitement, novelty and adventure. In contrast, people with low levels of OSL prefer and feel comfortable with low levels of activation (Raju, 1980; Richard and Chebat, 2016). This notion has been confirmed by empirical research, which has found that individuals with higher levels of OSL are more likely to become involved in novel, complex, intense or recreational activities than those individuals with low levels of OSL (Chang, 2017; Cho and Workman, 2014; Gu et al., 2016, 2018).

\subsection{The immersive experience of imagery}

Imagery (also known as mental imagery) has been outlined as an immersive experience that very much resembles an actual experience (Albers et al., 2013; Cumming and Ramsey, 2009; Pearson et al., 2015). More specifically, the construct of imagery captures the subjective experiences users might have when, stimulated by incoming cues from a medium, they evoke sensory images or emotions in their minds (Josiassen et al., 2016; MacInnis and Price, 1987; Yuille and Catchpole, 1977). Individuals are assumed to build, via imagery experiences, mental representations of the situations and the people they interact with (Rodríguez-Ardura and Meseguer-Artola, 2018). These representations are raised by perception and by memory (Naselaris et al., 2015; Pearson and Westbrook, 2015), and they lead users to re-experience the original external stimuli they are exposed to, and to create new combinations of them (Albers et al., 2013; Pearson et al., 2015).

Imagery might also be understood as an immersive experience that provides the individual with stimuli with which to reach his or her preferred level of stimulation. This is because imagery episodes generate content that is not limited in any way - so they might shape novel, complex or unrealistic scenarios (MacInnis and Price, 1987; Rodríguez-Ardura and Martínez-López, 2014; Wu and Holsapple, 2014).

\subsection{The experience of presence}

The notion of presence suggests that individuals, when exposed to cues from a technological device, might temporarily suspend their disbelief in the realness of the simulated virtual environment depicted by the medium and build an "illusion" in their minds through which they feel physically located in this alternative virtual environment (for a historical review see Lombard and Jones, 2015). Presence has been consistently portrayed as an immersive phenomenon through which the individual feels he or she is actually present in the 
alternative environment suggested by the technology (e.g. Cummings and Bailenson, 2016; Makransky et al., 2017; Sas and O'Hare, 2003; Slater et al., 1994).

Cognitive theories of presence describe how presence emerges after the individual creates credible representations in their mind, which are a particular "place" depicted by the technology (Saunders et al., 2011; Schubert et al., 2001; Schubert, 2009; Wirth et al., 2007). A well accepted cognitive theory on the formation of presence is the two-level model of spatial presence (Wirth et al., 2007). This model suggests that there are two key steps towards the experience of presence. In the first step, the user, in their mind, generates a cognitive space of the environment or situation suggested by the technology; and in the second step, they feel self-placed in this simulated realm. Therefore, it is not until the user builds a vivid mental representation of the reality suggested by the technology that they feel placed in there.

\subsection{Flow}

Of the three immersive experiences considered in this investigation (imagery, presence and flow), flow appears to be the closest to what might be considered the "quintessence" of a hedonic immersive experience (Rodríguez-Ardura and Meseguer-Artola, 2016, p. 508). This is because, from the m-Facebooker's viewpoint, flow experiences can be extremely gratifying; have no utilitarian or functional purposes; and, instead of being a means to achieving some other purposes, can become ends in themselves (Csikszentmihalyi, 1975a, b, 2008).

There is a certain degree of consensus (see review by Engeser and Schiepe-Tiska, 2012) on defining flow as proposed by Csikszentmihalyi' (1975a, b, 1997, 2008) seminal work. Consistent with this, flow is conceived as a highly positive state that individuals might enter into when, in their endeavour to overcome the challenges raised by a complex or demanding activity, they take their skills to the next level to master said activity (e.g. Csikszentmihalyi, 2008; Rodríguez-Ardura and Meseguer-Artola, 2017). In states of flow, individuals feel such bliss that the activity becomes beneficial and compelling for its own sake (Csikszentmihalyi, 2008; Nakamura and Csikszentmihalyi, 2009). Furthermore, online users under flow plunge so thoroughly and deeply into the virtual environment depicted by the technological device that they give their full attention to the online task, ignoring stimuli from their physical surroundings (Fang et al., 2013).

\subsection{Engagement}

An emerging stream of research is promoting the notion that there is a construct mediating the effects of the individual's immersion in social media on attitudinal and behavioural outcomes (Huang and Chen, 2018; Mollen and Wilson, 2010; Park et al., 2010); and that construct corresponds to what managers, marketers and IT practitioners call "engagement". Put differently, engagement is increasingly being conceived not as an outcome, but as an underlying subjective episode that facilitates a favourable attitude towards a brand, as well as positive behaviours such as a higher intention to continue using that brand (Algesheimer et al., 2005; Harrigan et al., 2017). For example, So et al. (2016) treated a positive evaluation of a brand and a commitment to re-patronise the brand as outcomes of engagement in their research on brand loyalty formation. Similarly, Huang and Chen (2018) suggested that users' engagement with a brand fan page in Facebook plays a part in their satisfaction with the service provided by the brand page and their intention to purchase the brand's products.

However, while it is easy to intuitively characterise "engaged" users as those individuals who have a positive and steady connection with the online value proposition, it is much harder to convey a formal working definition of engagement. There are some conceptualisations that place significant emphasis on what one could call the behavioural
Imagine, feel "there", and flow! 
ITP

32,4

926

outcomes of engagement, rather than on the engagement per se (see Calder et al., 2009). For example, Park et al. (2010) operationally defined engagement in terms of generating ideas and finding solutions, Lee, Kim and Kim (2011) and Lee, Kwak, Lim, Pedersen and Miloch (2011) as active participation in online settings, and Harmeling et al. (2017) as a user's positive and voluntary contribution "outside the core transaction" (p. 314).

Even though the aforementioned conceptualisations are more in line with the way in which the industry often measures engagement (Plummer et al., 2007), we concur with Calder et al. (2009) that they do not put the spotlight on the nature and meaning of engagement. Rather, we regard engagement as an intrinsic motivational force to interact and cooperate online (Algesheimer et al., 2005; Baldus et al., 2015; Hsu et al., 2012). This inner motivation is highly dependent on the context (Day et al., 1995; Dessart et al., 2016; Hollebeek, 2011) insofar as it is built upon the particular interaction between the user and the value proposition; and it is so compelling that it might orient the person in affective or behavioural ways (Brodie et al., 2013; Zheng et al., 2015).

\section{Research model and hypotheses}

Based on the theoretical background discussed above, we assume that m-Facebookers' immersive experiences of imagery, presence and flow are all psychological phenomena generated by the user's accumulated interaction and exploration within m-Facebook. We further study the links between these subjective phenomena and the personality construct of OSL, engagement and attitudinal and behavioural outcomes online (Figure 1).

New media users and non-users differ with respect to their needs for novelty and arousal or OSL (López-Bonilla and López-Bonilla, 2008; Richard and Chandra, 2005). In line with this, scientific inquiry into Facebookers' motivations has noted that, on this particular SNS, individuals pursue positive subjective experiences through elements that are new, intricate or diverse (Baek et al., 2011; Sashittal et al., 2012).

There have been conflicting results concerning a potential connection between OSL and imagery. Some studies have effectively observed that OSL is positively related to imagery (Franken and Rowland, 1990; Macrae et al., 2014; McDaniel et al., 2001), while others could not verify a presumed link between imagery and OSL (Lee, Kim and Kim, 2011; Lee, Kwak, Lim, Pedersen and Miloch, 2011; Parra and Argibay, 2012). However, the difficulties these latter studies encountered in finding a positive OSL-imagery connection could stem from the particular operationalisation used for imagery. In fact, they employ imagery-related measures (e.g. the frequency of imagery evocations of the usage of a certain product, the content of imagery, or the individual's proneness to fantasy) rather than centring on the imagery experience in and of itself (Franken and Rowland, 1990; McDaniel et al., 2001).

Figure 1.

Theoretical model

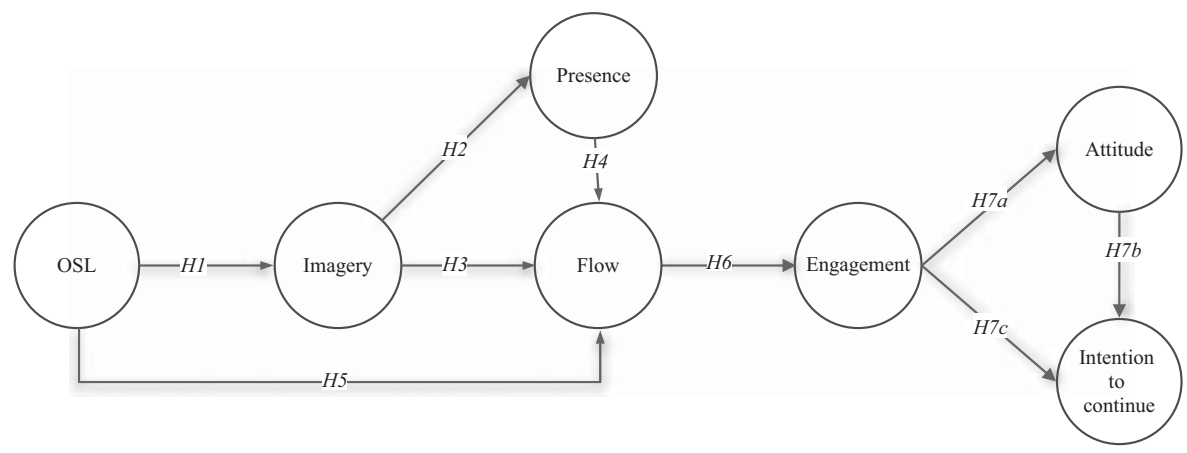


Besides, imagery experiences have two important characteristics that are in synchrony with the kind of stimuli (new, complex, diverse) sought by individuals who score highly in OSL (Gu et al., 2018; Richard and Chandra, 2005). First, imagery leads people to represent or create new, illusory situations in their minds (Rodríguez-Ardura and Martínez-López, 2014; $\mathrm{Wu}$ and Holsapple, 2014). Also, imagery is used to work successfully through burdensome situations (Cumming and Ramsey, 2009; Mattie and Munroe-Chandler, 2012). This leads us to hypothesise that m-Facebookers' OSL is a determinant of their imagery experiences:

H1. A higher OSL leads to a more intense imagery experience.

We also propose that stimuli coming from $\mathrm{m}$-Facebook are underlying drivers of presence experiences, but they are mediated by imagery (Pillai et al., 2013; Rodríguez-Ardura and Martínez-López, 2014). This reasoning is grounded in cognitive theories of presence, which defend that the user's experience of presence is preceded by the evocation of a simulated realm in his or her mind (Saunders et al., 2011; Schubert, 2009; Wirth et al., 2007). Based on Rodríguez-Ardura and Martínez-López (2014) and Rodríguez-Ardura and Meseguer-Artola (2016), we complement this view by suggesting that m-Facebookers build the mental representations of virtual spaces through inner experiences of imagery. Otherwise, m-Facebookers will only perceive what their senses capture from the SNS: a technological recreation of images, text and sounds (Franceschi et al., 2009; Rodríguez-Ardura and Martínez-López, 2014). In line with this, we put forward the hypothesis that the evocation of a simulated realm in the m-Facebooker's mind, via vivid mental imagery, leads to the experience of presence:

H2. A more intense imagery experience leads to a more intense presence experience.

There is an emerging stream that defends a connection between imagery and flow. The first evidence of this link was provided by several papers that reported successful imagery interventions in sports and their impact on enhancing flow (i.e. Jeong, 2012; Koehn et al., 2013; Nicholls et al., 2005; Pates et al., 2001) and a positive connection between imagery and flow in e-learning settings (Rodríguez-Ardura and Meseguer-Artola, 2016). An explanation may be offered on the basis of Paivio's (1985) analytical framework of imagery effects. This is because imagery can serve two functions: cognitive and motivational. So imagery might facilitate learning and memory processes (Mousa et al., 2013; Slagter et al., 2011), while helping individuals remain focused on the task at hand (Bodeck et al., 2015; Calmels et al., 2004; Kuan et al., 2018), feel confident in their personal skills (Koehn et al., 2013) and deal with challenges (Briley et al., 2017; Munroe et al., 2000). These mechanisms are indeed closely related to the skill-challenge and the focused attention aspects of flow. In accordance with these arguments, we suggest that the evocation of a simulated reality on m-Facebook, by way of vivid mental imagery, prompts flow:

H3. A more intense imagery experience leads to a more intense flow experience.

Presence experiences might also have a relevant role in flow. This is because, once the user has accepted the spatial dimensions of the alternative realm depicted by m-Facebook (via feelings of presence), their total absorption in the activity on this particular MSNS becomes much more attainable. This interpretation of the role of presence is theoretically supported by research on the phenomenon, which acknowledges two distinct facets in presence (Schubert, 2009; Wirth et al., 2007): a compelling feeling of being physically located in the environment depicted by the technology (Lombard and Ditton, 1997; Makransky et al., 2017), and an awareness of only those actions that can be performed in this virtual environment (Faiola et al., 2013; Sas and O'Hare, 2003). To put it another way: coupled with the individual's sense of being "inside" an alternative environment, the

Imagine, feel "there", and flow! 
individual in presence feels that he or she has left the immediate realm behind. In turn, this makes it more likely for the person to become engrossed in the online activity with active involvement and intrinsic interest - which are core components of flow (Csikszentmihalyi and Asakawa, 2016; Ho and Kuo, 2010).

Regardless of the strength of the abovementioned reasoning, a challenge to the potential relationship between presence and flow has been raised. Some researchers contend that presence is one of the key dimensions of flow (Kwak et al., 2014; Park et al., 2010; Shim et al., 2015). This can be attributed to the fact that presence and flow share some core elements, such as focused attention (Jin, 2011; Kim, 2011; Kim et al., 2011; Rodríguez-Ardura et al., 2016) and perceived control (Csikszentmihalyi et al., 2005; Klein, 2003; Rodríguez-Ardura et al., 2016); so, on the basis of these similarities, in a number of studies presence has been assimilated into the conceptualisation of flow experiences.

Nevertheless, our interpretation of presence as a separate, distinct experience is supported by several lines of evidence which, acknowledging the elements that presence and flow have in common, also highlight the uniqueness of each construct (Faiola et al., 2013; Huang et al., 2010; Piyathasanan et al., 2014). Moreover, a number of empirical enquires have reported that presence contributes to the formation of flow (e.g. Animesh et al., 2011; Bachen et al., 2016; Jin, 2011; Pelet et al., 2017; Rodríguez-Ardura et al., 2016). Consistent with this, we hypothesise that if users feel "present" in the environment depicted by m-Facebook, then they will report a greater likelihood of having experienced flow:

H4. A more intense presence experience leads to a more intense flow experience.

As seen before, the central idea of OSL theory (e.g. Steenkamp and Baumgartner, 1992; Zuckerman, 1979) is that high-OSL individuals are curiosity motivated and show exploratory behaviours. When exposed to complex and challenging stimuli online, they will be less likely to feel overwhelmed; rather, they will perceive their skills to be in balance with the demands raised by the virtual environment. They will also show more autotelic personality traits (Hoffman and Novak, 1996; Richard and Chebat, 2016). Therefore, it seems reasonable to presume that high-OSL m-Facebookers, in order to meet their heightened preferred level of stimulation, will be more inclined to interact intensively within $\mathrm{m}$-Facebook so as to find and face demanding, complex activities. Insofar as these activities will require their full attention and will be enjoyable in and of themselves, they will trigger flow:

H5. A higher OSL leads to a more intense flow experience.

In the focal context of $\mathrm{m}$-Facebook interaction, engagement might facilitate the $\mathrm{m}$-Facebooker thinking about the brand's or organisation's value proposition, perceiving it as relevant, or embracing a positive and active bond with the brand (Hollebeek et al., 2014; Potdar et al., 2018). Our stance is that the motivational force of engagement might be triggered by the m-Facebooker's episodes of flow (Pagani and Mirabello, 2011; Shin, 2018). This is because flow, while leading users to become fully engrossed in online tasks, also motivates them to pursue these tasks (Hollebeek, 2011; Landhäußer and Keller, 2012; Rodríguez-Ardura and Meseguer-Artola, 2017). Flow translates into peak cognitive processing, which is so captivating that it generates more persistent motivational drivers. Evidence from engagement literature, although not abundant, provides support for this link (Medhurst and Albrecht, 2016; Mollen and Wilson, 2010; Park et al., 2010). Therefore, it is reasonable to hypothesise that:

H6. A more intense flow experience leads to a higher level of engagement. 
As mentioned above, engagement may have substantial attitudinal and behavioural consequences (Huang and Chen, 2018; So et al., 2016). This is because engagement relates to how a brand's value proposition is motivationally relevant for the individual and, therefore, becomes an intrinsic path for committing to a positive and enduring relationship with the brand (Calder et al., 2009; van Doorn et al., 2010). For brands and organisations with a presence in $\mathrm{m}$-Facebook, the potential connection of engagement with attitude and re-usage intention is critical (Harrigan et al., 2017). The fragmentation of media usage has made it hard for many brands to find effective means of communication and interaction (Truong et al., 2010; Vernuccio and Ceccotti, 2015). So, in their attempt to generate favourable attitudes and retain users, they intensively employ m-Facebook and other SNSs (Harrigan et al., 2018) that allow users to contribute to the firm's marketing functions (Harmeling et al., 2017; Sanz-Blas et al., 2017).

An individual's engagement with m-Facebook might create a favourable attitude towards this MSNS. One rationale that helps to explain how engagement influences attitude formation is the elaboration likelihood model of persuasion, or ELM (Cacioppo and Petty, 1984; Petty and Cacioppo, 1981). ELM defends the assertion that, under conditions of high engagement, the individual generates their beliefs and attitudes using personally relevant information (Petty et al., 1983; Petty and Cacioppo, 1981, 1990). Engaged individuals, insofar as they are more committed to elaborating information, show a greater willingness to retrieve their personal mental models and compare them with the new pieces of information to which they are exposed. This supports the association of the new pieces of external information with the subjectively evaluative representations made by the individual, and leads them to form more accessible, consistent and enduring attitudes (Cyr et al., 2018; Petty and Cacioppo, 1986; SanJosé-Cabezudo et al., 2009). Once an attitude is built or modified through the described extensive elaboration process, this attitude will be more accessible and, therefore, might have a greater effect on the individual's behaviour (Kokkinaki and Lunt, 1997; Pierro et al., 2012).

Based on all of this, the position is that engagement brought about by the individual's experience on m-Facebook might be associated with favourable attitudes towards the medium; and also that both attitude and engagement can prompt continuance on $\mathrm{m}$-Facebook:

$H 7 a$. A more intense engagement leads to a more favourable attitude.

$H 7 b$. A more favourable attitude leads to a greater willingness to continue.

H7c. A more intense engagement leads to a greater willingness to continue.

\section{Methodology}

\subsection{Participants}

Data were collected from adults who had accessed Facebook Spain at least once in the month prior to the period in which the fieldwork was carried out. Due to the lack of Facebook member lists, it was not possible to identify and reach the members of the sample frame in order to obtain a probability sample. Therefore, we recruited participants by snowball sampling (Handcock and Gile, 2011): we drew the initial sample through a convenience method, and used chain-referral to obtain the rest of the sample. We ran this sampling method on Facebook, thereby benefitting from each respondent's personal social network to make referrals and recruit new respondents until a desirable sample size was reached. The advantages of this approach were reduced recruiting costs (Fang et al., 2014) and the potential respondent's increased willingness to participate in the survey and give truthful information (Baltar and Brunet, 2012). It is important to point out that snowball sampling on Facebook cannot be considered an entirely non-random technique, as even
Imagine, feel

"there", and flow! 
ITP

32,4

930

Table I

Descriptive statistics of the sample though it may start from a convenience sample, in the following waves it involves a semi-random selection of participants (Baltar and Brunet, 2012).

In order to minimise the time and cost of data gathering and further increase the participation rate, we used an online survey (Baltar and Brunet, 2012). We requested survey participants to provide their e-mail addresses. For selected cases, we checked the e-mail address provided to ensure the reliability of the data collected. During a period spanning two months, a total of 778 participants accessed the online survey. We excluded from the analysis all questionnaires with empty data fields, which resulted in a final sample of 416 valid questionnaires. For the purpose of our study, we used only those questionnaires (356 in total) in which participants reported that they regularly access Facebook via mobile devices.

The main concern about snowball sampling relates to sample selection bias. This is because individuals with larger personal social networks might recruit more peers, who may have similar characteristics (Johnston and Sabin, 2010); thus the sample might over-represent cohesive social networks. The demographic detail of the respondents' profile is shown in Table I. A total of 94.4 per cent of Facebookers who completed the questionnaire were over 25 years old, 64.4 per cent were women and 90.3 per cent used Spanish as their primary language. They provided a diverse sample, which potentially included Facebookers who were hard to recruit through conventional sampling methods, such as Spanish nationals travelling abroad and foreign residents with a preference for English rather than Spanish.

To examine non-response bias in the valid sample, we compared the respondents' age, gender and primary language spoken with those of the target population. While we detected significant differences between the distribution of males and females, for age and language the correlation indexes between the distributions of the total population and those in the sample were 0.85 and 1.00, respectively. Furthermore, we discarded the potential moderating effect of the gender dimension on the causal paths included in the model. The multi-group comparison technique (Sarstedt et al., 2011) yielded no significant moderating effect of gender. This implies that the sample exhibited acceptable representativeness.

\subsection{Measurement}

We measured the constructs in the model with multi-item scales previously validated in relevant literature, and adapted to our study context (Table II). To improve content validity, we pre-tested the scales among eight scholars in the field. These scholars were asked to comment on: the domain of the constructs, the wording precision and readability of

\begin{tabular}{llcr}
\hline Measure & Category & Population $^{\mathrm{a}}$ & Sample \\
\hline \multirow{2}{*}{ Age } & $18-24$ & 17.9 & 9.6 \\
& $25-34$ & 26.8 & 25.5 \\
& $35-44$ & 26.3 & 41.1 \\
& $45-54$ & 17.0 & 22.4 \\
Gender & $\geqslant 55$ & 12.0 & 1.4 \\
& Male & 45.4 & 35.6 \\
Language & Female & 54.6 & 64.4 \\
& Spanish & 90.9 & 90.3 \\
& English & 10.5 & 6.3 \\
& Catalan & 3.6 & 0.7
\end{tabular}

Note: ${ }^{\mathrm{a} O w l o o ~(2015)}$ 


\begin{tabular}{|c|c|c|c|c|c|}
\hline$\underline{\text { Constructs }}$ & Original scales & Adapted questionnaire scales & Cronbach's $\alpha$ & $\begin{array}{c}\text { Item-total } \\
\text { correlation } \\
\end{array}$ & "there", and \\
\hline \multirow[t]{5}{*}{ OSL } & \multirow{5}{*}{$\begin{array}{l}\text { Steenkamp and } \\
\text { Baumgartner } \\
\text { (1995) }\end{array}$} & $\begin{array}{l}\text { OSL1: I like to try new and different things rather } \\
\text { than continue doing the same old things }\end{array}$ & \multirow[t]{5}{*}{0.856} & 0.685 & \\
\hline & & $\begin{array}{l}\text { OSL2: I like a job that offers change, variety and } \\
\text { travel, even if it involves some danger }\end{array}$ & & 0.651 & \\
\hline & & OSL3: I like continually changing activities & & 0.739 & 931 \\
\hline & & $\begin{array}{l}\text { OSL4: when things get boring, I like to find some } \\
\text { new and unfamiliar experience }\end{array}$ & & 0.695 & \\
\hline & & $\begin{array}{l}\text { OSL5: I prefer an unpredictable way of life, full of } \\
\text { change, to a routine one }\end{array}$ & & 0.691 & \\
\hline \multirow[t]{3}{*}{ Imagery } & \multirow{3}{*}{$\begin{array}{l}\text { Babin and Burns } \\
\text { (1998), Walters } \\
\text { et al. (2012) }\end{array}$} & MI1: many images come to my mind & 0.929 & 0.813 & \\
\hline & & $\begin{array}{l}\text { MI2: the mental images that come to mind are } \\
\text { very clear }\end{array}$ & & 0.881 & \\
\hline & & $\begin{array}{l}\text { MI3: the mental images that come to mind form a } \\
\text { series of events in my mind which I am a } \\
\text { part of }\end{array}$ & & 0.872 & \\
\hline \multirow[t]{4}{*}{ Presence } & \multirow[t]{4}{*}{$\begin{array}{l}\text { Novak et al. } \\
(2000)\end{array}$} & $\begin{array}{l}\text { P1: I forget about my immediate surroundings } \\
\text { when I use Facebook }\end{array}$ & 0.837 & 0.629 & \\
\hline & & $\begin{array}{l}\text { P2: after using Facebook, I feel like I come back } \\
\text { to the "real world" after a journey }\end{array}$ & & 0.722 & \\
\hline & & $\begin{array}{l}\text { P3: when I use Facebook, I feel I am in a world } \\
\text { created by Facebook pages and resources }\end{array}$ & & 0.676 & \\
\hline & & $\begin{array}{l}\text { P4: when I use Facebook, my body is in the room, } \\
\text { but my mind is inside the world created by } \\
\text { the pages and resources I explore }\end{array}$ & & 0.764 & \\
\hline \multirow[t]{4}{*}{ Flow } & \multirow{4}{*}{$\begin{array}{l}\text { Novak et al. } \\
(2000)\end{array}$} & (Description of flow and instructions) & & & \\
\hline & & F1: I have experienced flow on Facebook & 0.883 & 0.795 & \\
\hline & & $\begin{array}{l}\text { F2: most of the time I use Facebook I feel that } \\
\text { I am in flow }\end{array}$ & & 0.775 & \\
\hline & & $\begin{array}{l}\text { F3: in general, how frequently would you say you } \\
\text { have experienced "flow" when using } \\
\text { Facebook? }\end{array}$ & & 0.846 & \\
\hline \multirow[t]{3}{*}{ Engagement } & \multirow{3}{*}{$\begin{array}{l}\text { McQuarrie and } \\
\text { Munson (1992) }\end{array}$} & $\mathrm{E} 1:$ is important & 0.886 & 0.795 & \\
\hline & & $\mathrm{E} 2$ : is relevant & & 0.779 & \\
\hline & & E3: means a lot to me & & 0.762 & \\
\hline \multirow[t]{3}{*}{ Attitude } & \multirow{3}{*}{$\begin{array}{l}\text { Childers et al. } \\
\text { (2001) }\end{array}$} & A1: inferior - superior & 0.828 & 0.637 & \\
\hline & & A2: poor - excellent & & 0.695 & \\
\hline & & A3: not worthwhile - worthwhile & & 0.731 & \\
\hline \multirow[t]{3}{*}{$\begin{array}{l}\text { Intention to } \\
\text { continue }\end{array}$} & \multirow[t]{3}{*}{$\begin{array}{l}\text { Moon and Kim } \\
(2001)\end{array}$} & $\begin{array}{l}\text { IC1: I will use Facebook on a regular basis } \\
\text { in the future }\end{array}$ & 0.870 & 0.803 & $\begin{array}{r}\text { Table II. } \\
\text { Questionnaire }\end{array}$ \\
\hline & & IC2: I will frequently use Facebook in the future & & 0.816 & \\
\hline & & IC3: I will strongly recommend others to use & & 0.646 & 1. \\
\hline
\end{tabular}

individual items, the item response form, and the sequence and consistency of items. On the basis of the feedback they provided, the wording and the sequence of a few items were refined. The questionnaire was made available in the three languages most used by users of Facebook Spain (Spanish, English and Catalan).

\section{Analysis and results}

\subsection{Measurement model}

The initial exploratory factor analysis showed that there were seven factors with an eigenvalue greater than 1 , which all together explained 76.54 per cent of the information. These factors corresponded to the constructs in the model, as all item loadings associated 
ITP

32,4

932

with the expected factor were higher than 0.7 (see Table III). These results give support to the convergent validity.

The confirmatory factor analysis showed that the measures of the constructs were robust in terms of their convergent validity (Table IV). The CR of each construct exceeded 0.7 , and in all cases the AVE was greater than 0.50. Furthermore, CR was always greater than AVE.

\begin{tabular}{|c|c|c|c|c|c|c|c|}
\hline & $\begin{array}{c}\text { OSL } \\
\lambda=6.846 \\
\text { Var: } 28.53 \%\end{array}$ & $\begin{array}{c}\text { Imagery } \\
\lambda=2.966 \\
\text { Var: } 12.36 \%\end{array}$ & $\begin{array}{c}\text { Presence } \\
\lambda=3.248 \\
\text { Var: } 13.53 \%\end{array}$ & $\begin{array}{c}\text { Flow } \\
\lambda=1.837 \\
\text { Var: } 7.66 \%\end{array}$ & $\begin{array}{c}\text { Engagement } \\
\lambda=1.164 \\
\text { Var: } 4.85 \%\end{array}$ & $\begin{array}{c}\text { Attitude } \\
\lambda=1.001 \\
\text { Var: } 4.17 \%\end{array}$ & $\begin{array}{c}\text { Intention to } \\
\text { continue } \\
\lambda=1.306 \\
\text { Var: } 5.44 \%\end{array}$ \\
\hline OSL1 & 0.716 & 0.099 & -0.029 & 0.010 & 0.008 & 0.153 & 0.093 \\
\hline OSL2 & 0.777 & 0.077 & -0.008 & 0.019 & 0.055 & -0.020 & 0.021 \\
\hline OSL3 & 0.835 & 0.055 & 0.034 & 0.117 & 0.028 & -0.070 & 0.104 \\
\hline OSL4 & 0.823 & -0.014 & 0.041 & 0.021 & 0.053 & -0.023 & -0.050 \\
\hline OSL5 & 0.808 & 0.011 & 0.107 & 0.075 & 0.002 & 0.052 & 0.003 \\
\hline MI1 & 0.053 & 0.871 & 0.155 & 0.141 & 0.096 & 0.128 & 0.069 \\
\hline MI2 & 0.080 & 0.897 & 0.164 & 0.138 & 0.120 & 0.118 & 0.127 \\
\hline MI3 & 0.101 & 0.906 & 0.118 & 0.086 & 0.107 & 0.139 & 0.096 \\
\hline $\mathrm{P} 1$ & 0.017 & 0.078 & 0.723 & 0.286 & 0.110 & -0.047 & 0.048 \\
\hline $\mathrm{P} 2$ & 0.021 & 0.098 & 0.827 & 0.209 & 0.041 & 0.020 & 0.114 \\
\hline P3 & 0.069 & 0.108 & 0.776 & 0.048 & 0.015 & 0.131 & -0.079 \\
\hline $\mathrm{P} 4$ & 0.025 & 0.185 & 0.773 & 0.349 & 0.137 & 0.047 & -0.026 \\
\hline $\mathrm{F} 1$ & 0.077 & 0.207 & 0.228 & 0.850 & 0.125 & -0.009 & 0.074 \\
\hline $\mathrm{F} 2$ & 0.093 & 0.094 & 0.382 & 0.789 & 0.127 & 0.093 & 0.015 \\
\hline F3 & 0.101 & 0.091 & 0.293 & 0.859 & 0.123 & 0.075 & 0.119 \\
\hline $\mathrm{E} 1$ & 0.043 & 0.118 & 0.118 & 0.053 & 0.853 & 0.192 & 0.212 \\
\hline $\mathrm{E} 2$ & 0.085 & 0.140 & 0.063 & 0.138 & 0.854 & 0.208 & 0.123 \\
\hline E3 & 0.028 & 0.089 & 0.114 & 0.210 & 0.773 & 0.162 & 0.339 \\
\hline A1 & 0.017 & 0.168 & 0.048 & 0.076 & 0.107 & 0.781 & 0.184 \\
\hline $\mathrm{A} 2$ & 0.050 & 0.118 & 0.028 & 0.016 & 0.166 & 0.829 & 0.143 \\
\hline A3 & 0.013 & 0.078 & 0.074 & 0.035 & 0.235 & 0.813 & 0.245 \\
\hline IC1 & 0.096 & 0.102 & -0.063 & 0.068 & 0.206 & 0.168 & 0.875 \\
\hline IC2 & 0.081 & 0.117 & 0.019 & 0.070 & 0.154 & 0.171 & 0.896 \\
\hline IC3 & -0.011 & 0.075 & 0.094 & 0.052 & 0.250 & 0.311 & 0.712 \\
\hline
\end{tabular}

Table III.

Item cross-loadings,

construct eigenvalues

and variance explained 
Our results lend support to the discriminant validity of all the constructs: the MSV and the ASV of each construct are both below its AVE; and the square root of each construct's AVE is greater than the values of the correlations between that construct and the remaining constructs.

Internal reliability of the constructs was also examined (see Table II). In every case, Cronbach's $\alpha$ value is greater than 0.70 , and the item-to-total correlation is above 0.60 .

\subsection{Common method variance (CMV)}

$\mathrm{CMV}$ can cause systematic issues in the measurement of the covariance between constructs and threaten the validity of the findings. In order to avoid misinterpreting scale items and reduce random responses, we adapted the scale items to the particular environment of Facebook. In addition, we refined the items on the basis of in-depth interviews with scholars in the field. To diminish the survey respondents' reluctance to being evaluated and make them less likely to report consistent and socially desirable answers, the anonymity of all respondents was guaranteed.

We checked the effectiveness of these preventive measures using two tests: Harman's single factor test, and the Bagozzi test. First, the factorial analysis showed a seven-factor solution (Table III), in which seven components had an eigenvalue greater than 1 and the explained aggregate variance was 75.54 per cent. Second, the highest correlation observed was between the flow and presence constructs (see Table III), which is clearly lower than 0.90. These results support the idea that our analyses do not have significant CMV biases.

\subsection{Structural model}

If we adjust the $\chi^{2}$ statistic to the degrees of freedom of the model, we get an acceptable result of 1.65 (see Table V). In addition, GFI and AGFI were both greater than the minimum acceptable value, and SRMR and RMSEA were under the upper threshold. These good measures of fit allow us to assert that the model represents 91.5 per cent of the variance associated with the sample's variance-covariance matrix.

\begin{tabular}{lcc}
\hline Fit index & Value & Recommended cut-off value \\
\hline Absolute fit measures & & \\
$\chi^{2} / \mathrm{df}$ & 1.653 & $<5.000$ \\
GFI & 0.915 & $>0.800$ \\
AGFI & 0.895 & $>0.800$ \\
SRMR & 0.071 & $<0.080$ \\
RMSEA & 0.043 & $<0.080$ \\
Incremental fit measures & & \\
TLI & 0.965 & $>0.900$ \\
NFI & 0.926 & $>0.900$ \\
CFI & 0.969 & $>0.950$ \\
Parsimonious fit measures & & $>0.500$ \\
PGFI & 0.741 & $>0.500$ \\
PNFI & 0.816 & $>0.500$ \\
PCFI & 0.853 &
\end{tabular}

Notes: df, degrees of freedom; GFI, goodness-of-fit index; AGFI, adjusted goodness-of-fit index; SRMR, standardised root mean square residual; RMSEA, root mean square error of approximation; TLI, Tucker-Lewis index; NFI, normed fit index; CFI, comparative fit index; PGFI, parsimonious goodness-of-fit index; PNFI, parsimonious normed fit index; PCFI, parsimonious comparative fit index

Imagine, feel "there", and flow!

\section{3}


ITP

32,4

934

When compared with the null model, the hypothesised model yielded a better incremental fit. The NFI and the TLI surpassed the minimum required value, and the CFI was greater that the suggested lower threshold. The parsimonious fit measures were also good: the PGFI, the PNFI and the PCFI were all greater than the recommended levels.

We used the results of the parameters' estimation associated with each causal link to examine the validity of our hypotheses (Table VI). All the estimates were positive and significantly different from zero, so our hypotheses are supported.

We obtained the coefficient of the indirect effect between imagery and flow mediated by presence, and confirmed its significance through the $z$-test (see Table VII). Taking into account that there was a significant direct effect from imagery and flow, the result of the $z$-test implies that presence complementarily mediates the association between imagery and flow. Following the same steps, we confirmed the indirect link of engagement to intention to continue through attitude.

\section{Discussion}

\subsection{Theoretical implications}

Overall, this paper contributes to the search for a better understanding of users' immersive experiences in hedonic media products. This is because studies on user immersive experiences in the broader spectrum of online media have not delved deeply into the imaginative and sensation-seeking facets of hedonic experiences raised by virtual environments. In fact, most of these studies have been situated in utilitarian usage contexts, or have adopted a generic approach to the hedonic value of media products (Bilgihan et al., 2015; Pöyry et al., 2013; Yang and Lin, 2014). Furthermore, they have largely considered only a single type of user immersive experience, either the cognitive states of flow or the feelings of presence, and they have overlooked the inner experiences of imagery (Cummings and Bailenson, 2016; Kaur, Dhir and Rajala, 2016; Kaur, Dhir, Chen and Rajala, 2016; Liu et al., 2016; Vonkeman et al., 2017). Our study expands on this previous research by

\begin{tabular}{|c|c|c|c|c|c|c|}
\hline$H i$ & Relationships & $\beta$ & $\beta^{*}$ & $\mathrm{SE}$ & $\mathrm{CV}$ & $p$-value \\
\hline$H 1(+)$ & OSL $\rightarrow$ imagery & 0.340 & 0.179 & 0.113 & 0.006 & 0.003 \\
\hline$H 2(+)$ & Imagery $\rightarrow$ presence & 0.285 & 0.388 & 0.044 & 6.486 & 0.000 \\
\hline$H 3(+)$ & Imagery $\rightarrow$ flow & 0.117 & 0.105 & 0.056 & 2.084 & 0.037 \\
\hline$H 4(+)$ & Presence $\rightarrow$ flow & 0.964 & 0.633 & 0.098 & 9.846 & 0.000 \\
\hline$H 5(+)$ & $\mathrm{OSL} \rightarrow$ flow & 0.270 & 0.127 & 0.102 & 2.655 & 0.008 \\
\hline$H 6(+)$ & Flow $\rightarrow$ engagement & 0.346 & 0.399 & 0.050 & 6.933 & 0.000 \\
\hline$H 7 a(+)$ & Engagement $\rightarrow$ attitude & 0.408 & 0.543 & 0.044 & 9.321 & 0.000 \\
\hline$H 7 b(+)$ & Attitude $\rightarrow$ intention to continue & 0.402 & 0.320 & 0.081 & 4.961 & 0.000 \\
\hline$H 7 c(+)$ & Engagement $\rightarrow$ intention to continue & 0.345 & 0.366 & 0.060 & 5.775 & 0.000 \\
\hline
\end{tabular}

Table VI.

Hypotheses, path coefficients and results

Notes: $\beta$, estimates; $\beta^{*}$, standardised estimates; SE, standard error of the regression weight; $\mathrm{CV}$, critical ratio value for regression weight

Table VII.

Significance of the indirect effects

\begin{tabular}{lccccr}
\hline Relationships & $\beta$ & SE & Indirect effect & $z$ & $p$-value \\
\hline Imagery $\rightarrow$ presence & 0.285 & 0.044 & 0.275 & 2.883 & 0.004 \\
Presence $\rightarrow$ flow & 0.964 & 0.098 & & & \\
Engagement $\rightarrow$ attitude & 0.408 & 0.044 & 0.164 & 4.411 & 0.000 \\
Attitude $\rightarrow$ intention to continue & 0.402 & 0.081 & & & \\
\hline
\end{tabular}


exploring the sensation-seeking and imagery facets of hedonic consumption online, along with their interplay with online flow and presence. By so doing, it offers a coherent picture of the complexity of the experiential elements of a user's hedonic usage of mobile products.

This research also contributes to an understanding of users' imagery online, which can be a key experiential facet of online hedonic consumption. We provide evidence that links imagery not only with sensation-seeking, but also with immersive experiences of presence and flow. These findings suggest that the user's personality trait of OSL becomes a driving force of online hedonic consumption, and that the imaginative, inner constructions of reality generated by user interaction in the medium unleash immersive experiences. The findings echo those of Rodríguez-Ardura and Meseguer-Artola (2016) in the context of e-learning continuance, in that inner multi-sensory representations, raised by way of imagery, facilitate the individual's sense of spatial immersion in the virtual environment as well as their full absorption in the activity and the events happening online.

Furthermore, this study complements Faiola et al. (2013), Rodríguez-Ardura et al. (2016) and Shin's (2018) findings that presence and flow are distinct constructs. Indeed, we show, within the context of m-Facebook usage, that flow has a mediating role between users' presence feelings and their engagement with the media. The latter result is indeed in synchrony with a recent study by Shin (2018), who found that, in virtual reality, presence does not steer users towards engagement; instead, it is mediated by flow. We further concur with Shin (2018) that users form immersive experiences on their own and do so because they want to become immersed. In other words, the intentional and active nature of presence, flow and engagement and the connections between them suggest that, when plunged into immersive experiences with digital technologies, users are active agents that willingly put cognitive effort into processing content and interacting with other users in meaningful and ongoing ways. Hence, immersive experiences can be regarded as thoughtful processes of a very dynamic nature.

Finally, but importantly, this study provides the first line of evidence of the driving force of OSL in immersive experiences of flow. The OSL-flow connection had been proposed by Hoffman and Novak (1996) and Woszczynski et al. (2002), but unfortunately, and to the best of our knowledge, no previous study had explored this link empirically until now. Our findings indicate that users who have high-OSL scores, insofar as they are more likely to exhibit sensation-seeking behaviours and show autotelic personality traits, tend to explore and interact more within the virtual environment. Consequently, they are more willing to enjoy the challenges and stimulation of virtual environments, which ultimately leads to flow. This is also consistent with the findings of recent studies, which have reported that users' general disposition to undergo immersive experiences is dependent on personality traits (Chesney et al., 2016; Shin and Biocca, 2018).

\subsection{Practical implications}

The increasing use of m-Facebook and other hedonic MSNS and mobile products encourages managers and practitioners to try to understand a user's immersive experiences on the new hedonic media, no longer regarding users' inner experiences as black boxes. Our study provides an understanding that meets these practitioners' goals.

Chua and Chua (2017) suggest that the user's personality profile is related to Facebook usage, even though other factors, apart from personality, might also be relevant. In line with this, we show that the user's personality trait of OSL is directly connected to two relevant facets of the user's immersive experience on m-Facebook (i.e. imagery and flow); and that is how it ultimately prompts user engagement and positive intentional behaviours towards Facebook.

The virtual environments depicted by m-Facebook are imagined (and imaginary) realms. In their minds, m-Facebookers construe representations about situations and personal
Imagine, feel "there", and flow! 
connections they learn about on this MSNS. They imagine what other Facebookers look like in real life and how events will develop; and they place their own self-images in those events. An emphasis on content and configurations that foster $m$-Facebookers' imaginations and their sense of being "there", within the virtual environment, are key to building a superior value proposition online.

Accordingly, we suggest that brands and organisations enhance users' immersive experiences with narratives, interactions and sensorial resources that lead users to form impressive and memorable mental images, coupled with information structures and designs that provide spatial cues and direction to the user's endeavour (instructions to imagine, informational signals that elicit memories and spatial dimensions, etc.). Content and functionalities should be capable of transporting users and making them feel they are part of a virtual environment. In addition, they should be rewarding by themselves either because of the realm they give access to, or because of the mechanisms they provide for exploration and socialisation. In addition to this, they should offer activities that provide a sense of challenge while users perceive they are in control and can meet the demands.

Our model might be of further use at an operational level, as it encourages exploration of the appropriate content and functionalities of each new value proposition on $\mathrm{m}$-Facebook. Indeed, the set of measures of immersive experiences we offer can serve as evaluative tools to examine the experiential capacity of the brand's/organisation's pages on m-Facebook.

\subsection{Limitations and further research}

The contributions of this paper are constrained by three unresolved questions, which offer avenues for future research. First, we have not delineated an operational construct of the user's immersive experience on $\mathrm{m}$-Facebook as a whole. Instead, we have taken a less risky scientific approach consisting of examining the validity and interplay of three immersive experiences (i.e. imagery, presence and flow), already identified in relevant, albeit scattered, literature on consumer behaviour and human-computer interaction. Therefore, we regard our model as a first step towards the aim of having a validated construct of the m-Facebook immersive experience.

Second, the predictive generalisation of the findings is limited, since participants were recruited with a snowball sampling technique and all of them came from the same target population (i.e. users of Facebook Spain). Despite the unlikely possibility that spurious correlations could exist due to common method bias, it would be useful if future studies extended the external validity of the causal paths included in our model, confirming them in various samples. Spanish society, characterised by being neither very collectivist nor extremely individualist and with values traditionally associated with feminine roles (Spector et al., 2001), might influence individuals' interactions and social relationships online. Therefore, further research is needed to consider more comprehensive samples and examine whether cultural differences moderate key relationships in our model. Furthermore, MSNSs differ in their levels of media richness, amount of self-presentation, social interaction functionalities and hedonic value. Because our survey respondents were m-Facebookers, it would be interesting to examine the reasons for engagement among users of other MSNSs (e.g. Twitter, Instagram, YouTube) and compare those findings with the insights obtained from our model.

Third, our operationalisation of engagement is limited to one dimension (i.e. importance); thus, it might not capture all the construct's properties. So far, the multidimensional measures of engagement that have been developed (Baldus et al., 2015; Dessart et al., 2016; Hollebeek et al., 2014; So et al., 2014) are very different from one another and have not been validated yet across a range of contexts and product media, so none of them has become a benchmark. Therefore, researchers might wish to explore the composite nature of engagement, validate a pioneering composite scale, and use it in our model. 


\section{Conclusion}

This is one of the first studies to tackle m-Facebookers' immersive experiences at the individual level, and to investigate their psychological nature and interplay. The findings are of particular significance because they offer a close look at the individual's inner experiences of imagery, presence and flow and show their distinct, immersive nature and interconnections. The model predicts that these three immersive experiences lead to the $\mathrm{m}$ Facebooker's engagement and continuance, and the empirical test supports this prediction. Also, the study shows that flow experiences mediate the presence-engagement relationship, and that the personality trait of OSL facilitates the emergence of both imagery and flow experiences. An additional contribution of this paper lies in confirming the role of engagement as a subjective episode that mediates the effects of users' immersive experiences and their attitudes and behavioural intentions towards m-Facebook. In the future, further research will be conducted to develop and validate an integrative construct of a higher order that captures the key characteristics of immersive experiences at the psychological level.

\section{References}

Alba, J.W. and Williams, E.F. (2013), "Pleasure principles: a review of research on hedonic consumption", Journal of Consumer Psychology, Vol. 23 No. 1, pp. 2-18.

Albers, A.M., Kok, P., Toni, I., Dijkerman, H.C. and de Lange, F.P. (2013), "Shared representations for working memory and mental imagery in early visual cortex", Current Biology, Vol. 23 No. 15, pp. 1427-1431.

Algesheimer, R., Dholakia, U.M. and Herrmann, A. (2005), "The social influence of brand community: evidence from European car clubs", Journal of Marketing, Vol. 69 No. 3, pp. 19-34.

Anderson, B., Fagan, P., Woodnutt, T. and Chamorro-Premuzic, T. (2012), "Facebook psychology: popular questions answered by research", Psychology of Popular Media Culture, Vol. 1 No. 1, pp. 23-37.

Animesh, A., Pinsonneault, A., Yang, S.-B. and Wonseok, O. (2011), "And odyssey into virtual worlds: exploring the impacts of technological and spatial environments on intention to purchase virtual products”, MIS Quarterly, Vol. 35 No. 3, pp. 789-810.

Babin, L.A. and Burns, A.C. (1998), "A modified scale for the measurement of mental imagery", Psychology and Marketing, Vol. 15 No. 3, pp. 261-278.

Bachen, C.M., Hernández-Ramos, P., Raphael, C. and Waldron, A. (2016), "How do presence, flow, and character identification affect players' empathy and interest in learning from a serious computer game?", Computers in Human Behavior, Vol. 64, pp. 77-87, available at: www.sciencedirect.com/ science/article/pii/S074756321630471X

Baek, K., Holton, A., Harp, D. and Yaschur, C. (2011), "The links that bind: uncovering novel motivations for linking on Facebook", Computers in Human Behavior, Vol. 27 No. 6, pp. 2243-2248.

Baldus, B.J., Voorhees, C. and Calantone, R. (2015), "Online brand community engagement: scale development and validation”, Journal of Business Research, Vol. 68 No. 5, pp. 978-985.

Baltar, F. and Brunet, I. (2012), "Social research 2.0: virtual snowball sampling method using Facebook", Internet Research, Vol. 22 No. 1, pp. 57-74.

Barreto, A.M. (2013), "Do users look at banner ads on Facebook?", Journal of Research in Marketing, Vol. 7 No. 2, pp. 119-139.

Ben-Ur, J., Mai, E. (Shirley) and Yang, J. (2015), "Hedonic consumption in virtual reality”, Journal of Internet Commerce, Vol. 14 No. 3, pp. 406-423.

Bilgihan, A., Kandampully, J. and Zhang, T. (2016), "Towards a unified customer experience in online shopping environments", International Journal of Quality and Service Sciences, Vol. 8 No. 1, pp. 102-119. 
Bodeck, S., Lappe, C. and Evers, S. (2015), "Tic-reducing effects of music in patients with Tourette's syndrome: self-reported and objective analysis", Journal of the Neurological Sciences, Vol. 352 Nos 1-2, pp. 41-47.

Bolton, R.N., Gustafsson, A., McColl-Kennedy, J., Sirianni, N.J. and Tse, D.K. (2014), "Small details that make big differences: a radical approach to consumption experience as a firm's differentiating strategy", Journal of Service Management, Vol. 25 No. 2, pp. 253-274.

Briley, D.A., Rudd, M. and Aaker, J. (2017), "Cultivating optimism: how to frame your future during a health challenge", Journal of Consumer Research, Vol. 44 No. 4, pp. 895-915.

Brodie, R.J., Hollebeek, L.D., Juric, B. and Ilic, A. (2011), "Customer engagement: conceptual domain, fundamental propositions, and implications for research", Journal of Service Research, Vol. 14 No. 3, pp. 252-271.

Brodie, R.J., Ilic, A., Juric, B. and Hollebeek, L.D. (2013), "Consumer engagement in a virtual brand community: an exploratory analysis", Journal of Business Research, Vol. 66 No. 1, pp. 105-114.

Cacioppo, J.T. and Petty, R.E. (1984), "The elaboration likelihood model of persuasion”, Advances in Consumer Research, Vol. 11 No. 1, pp. 673-675.

Calder, B.J., Malthouse, E.C. and Schaedel, U. (2009), "An experimental study of the relationship between online engagement and advertising effectiveness", Journal of Interactive Marketing, Vol. 23 No. 4, pp. 321-331.

Calmels, C., Berthoumieux, C. and D'Arripe-Longueville, F. (2004), "Effects of an imagery training program on selective attention of national softball players", Sport Psychologist, Vol. 18 No. 3, pp. 272-296.

Chang, Y. (2017), "Why do young people multitask with multiple media? Explicating the relationships among sensation seeking, needs, and media multitasking behavior”, Media Psychology, Vol. 20 No. 4 , pp. $685-703$.

Chaouali, W. (2016), "Once a user, always a user: enablers and inhibitors of continuance intention of mobile social networking sites", Telematics and Informatics, Vol. 33 No. 4, pp. 1022-1033.

Chesney, T., Chuah, S.-H., Hoffmann, R., Hui, W. and Larner, J. (2016), "How user personality and social value orientation influence avatar-mediated friendship", Information Technology \& People, Vol. 29 No. 4, pp. 688-716.

Cheung, C.M.K., Chiu, P.-Y. and Lee, M.K.O. (2011), "Online social networks: why do students use Facebook?”, Computers in Human Behavior, Vol. 27 No. 4, pp. 1337-1343.

Childers, T.L., Carr, C.L., Peck, J. and Carson, S. (2001), "Hedonic and utilitarian motivations for online retail shopping behavior", Journal of Retailing, Vol. 77 No. 4, pp. 511-535.

Cho, S. and Workman, J.E. (2014), "Influences of gender, need for affect, and tolerance for risk-taking on use of information sources", Journal of Fashion Marketing and Management, Vol. 18 No. 4, pp. 465-482.

Chua, Y.P. and Chua, Y.P. (2017), "Do computer-mediated communication skill, knowledge and motivation mediate the relationships between personality traits and attitude toward Facebook?", Computers in Human Behavior, Vol. 70, pp. 51-59, available at: www.sciencedirect.com/science/ article/pii/S0747563216308585

Csikszentmihalyi, M. (1975a), Beyond Boredom and Anxiety, Jossey-Bass, San Francisco, CA.

Csikszentmihalyi, M. (1975b), "Play and intrinsic rewards", Journal of Humanistic Psychology, Vol. 15 No. 3, pp. 41-63. 
Csikszentmihalyi, M. (1997), Finding Flow: The Psychology of Engagement with Everyday Life, Basic Books, New York, NY.

Csikszentmihalyi, M. (2008), Flow: The Psychology of Optimal Experience, Harper and Row, New York, NY.

Csikszentmihalyi, M. and Asakawa, K. (2016), "Universal and cultural dimensions of optimal experiences”, Japanese Psychological Research, Vol. 58 No. 1, pp. 4-13.

Csikszentmihalyi, M., Abuhamdeh, S. and Nakamura, J. (2005), "Flow", in Elliot, A.J. and Dweck, C.S. (Eds), Handbook of Competence and Motivation, Guilford Press, New York, NY, pp. 598-608.

Cumming, J. and Ramsey, R. (2009), "Imagery interventions in sport”, in Mellalieu, S.D. and Hanton, S. (Eds), Advances in Applied Sport Psychology: A Review, Routledge, Milton Park, pp. 5-36.

Cummings, J.J. and Bailenson, J.N. (2016), "How immersive is enough? A meta-analysis of the effect of immersive technology on user presence”, Media Psychology, Vol. 19 No. 2, pp. 272-309.

Cyr, D., Head, M., Lim, E. and Stibe, A. (2018), "Using the elaboration likelihood model to examine online persuasion through website design", Information and Management, Vol. 55 No. 7, pp. $807-821$

Day, E., Stafford, M.R. and Camacho, A. (1995), "Opportunities for involvement research: a scaledevelopment approach”, Journal of Advertising, Vol. 24 No. 3, pp. 69-75.

Dessart, L., Veloutsou, C. and Morgan-Thomas, A. (2016), "Capturing consumer engagement: duality, dimensionality and measurement", Journal of Marketing Management, Vol. 32 Nos 5-6, pp. 399-426.

Duffett, R.G. (2015), "The influence of Facebook advertising on cognitive attitudes amid Generation Y", Electronic Commerce Research, Vol. 15 No. 2, pp. 243-267.

Engeser, S. and Schiepe-Tiska, A. (2012), "Historical lines and an overview of current research on flow", in Engeser, S. (Ed.), Advances in Flow Research, Springer-Verlag New York, New York, NY, pp. 1-22.

Facebook (2017), "Company info I Stats", available at: https://newsroom.fb.com/company-info/ (accessed 14 June 2017).

Faiola, A., Newlon, C., Pfaff, M. and Smyslova, O. (2013), "Correlating the effects of flow and telepresence in virtual worlds: enhancing our understanding of user behavior in game-based learning”, Computers in Human Behavior, Vol. 29 No. 3, pp. 1113-1121.

Fang, J., Wen, C. and Prybutok, V. (2014), “An assessment of equivalence between paper and social media surveys: the role of social desirability and satisficing", Computers in Human Behavior, Vol. 30, pp. 335-343, available at: www.sciencedirect.com/science/article/pii/S0747563213003476

Fang, X., Zhang, J. and Chan, S.S. (2013), "Development of an instrument for studying flow in computer game play", International Journal of Human-Computer Interaction, Vol. 29 No. 7, pp. 456-470.

Fiore, A.M., Jin, H.J. and Kim, J. (2005), "For fun and profit: hedonic value from image interactivity and responses toward an online store", Psychology and Marketing, Vol. 22 No. 8, pp. 669-694.

Franceschi, K., Lee, R.M., Zanakis, S.H. and Hinds, D. (2009), "Engaging group e-learning in virtual worlds”, Journal of Management Information Systems, Vol. 26 No. 1, pp. 73-100.

Franken, R.E. and Rowland, G.L. (1990), "Sensation seeking and fantasy", Personality and Individual Differences, Vol. 11 No. 2, pp. 191-193.

Gentile, C., Spiller, N. and Noci, G. (2007), "How to sustain the customer experience: an overview of experience components that co-create value with the customer", European Management Journal, Vol. 25 No. 5, pp. 395-410.

Goggin, G. (2014), "Facebook's mobile career”, New Media \& Society, Vol. 16 No. 7, pp. 1068-1086.

Gu, R., Oh, L.-B. and Wang, K. (2016), "Multi-homing on SNSs: the role of optimum stimulation level and perceived complementarity in need gratification", Information and Management, Vol. 53 No. 6, pp. 752-766.

Gu, R., Jiang, Z. (Jack), Oh, L.-B. and Wang, K. (2018), "Exploring the impact of optimum stimulation level on individual perceptions of IT innovations: a trait hierarchical model perspective", Data Base for Advances in Information Systems, Vol. 49 No. 1, pp. 67-91. 
Ha, Y.W., Kim, J., Libaque-Saenz, C.F., Chang, Y. and Park, M.-C. (2015), "Use and gratifications of mobile SNSs: Facebook and KakaoTalk in Korea", Telematics and Informatics, Vol. 32 No. 3, pp. 425-438.

Handcock, M.S. and Gile, K.J. (2011), "On the concept of snowball sampling”, Sociological Methodology, Vol. 41 No. 1, pp. 367-371.

Harmeling, C.M., Moffett, J.W., Arnold, M.J. and Carlson, B.D. (2017), "Toward a theory of customer engagement marketing", Journal of the Academy of Marketing Science, Journal of the Academy of Marketing Science, Vol. 45 No. 3, pp. 312-335.

Harrigan, P., Evers, U., Miles, M. and Daly, T. (2017), "Customer engagement with tourism social media brands", Tourism Management, Vol. 59, pp. 597-609, available at: www.sciencedirect.com/ science/article/pii/S0261517716301753

Harrigan, P., Evers, U., Miles, M.P. and Daly, T. (2018), "Customer engagement and the relationship between involvement, engagement, self-brand connection and brand usage intent", Journal of Business Research Vol. 88, pp. 388-396, available at: www.sciencedirect.com/science/article/abs/ pii/S0148296317304927

Hebb, D.O. (1955), "Drives and the C.N.S. (conceptual nervous system)", Psychological Review, Vol. 62 No. 4, pp. 243-254.

Helm, R. and Landschulze, S. (2009), "Optimal stimulation level theory, exploratory consumer behaviour and product adoption: an analysis of underlying structures across product categories", Review of Managerial Science, Vol. 3 No. 1, pp. 41-73.

Hirschman, E.C. (1983), "Predictors of self-projection, fantasy fulfillment, and escapism", Journal of Social Psychology, Vol. 120 No. 1, pp. 63-76.

Hirschman, E.C. and Holbrook, M.B. (1982), "Hedonic consumption: emerging concepts, methods and propositions", Journal of Marketing, Vol. 46 No. 3, pp. 92-101.

Ho, L.-A. and Kuo, T.-H. (2010), "How can one amplify the effect of e-learning? An examination of hightech employees' computer attitude and flow experience", Computers in Human Behavior, Vol. 26 No. 1, pp. 23-31.

Hoffman, D.L. and Novak, T.P. (1996), "Marketing in hypermedia computer-mediated environments: conceptual foundations", Journal of Marketing, Vol. 60 No. 3, pp. 50-68.

Holbrook, M.B. and Hirschman, E.C. (1982), "The experiential aspects of consumption: consumer fantasies, feelings, and fun”, Journal of Consumer Research, Vol. 9 No. 2, pp. 132-140.

Hollebeek, L.D. (2011), "Demystifying customer brand engagement: exploring the loyalty nexus", Journal of Marketing Management, Vol. 27 Nos 7-8, pp. 785-807.

Hollebeek, L.D., Glynn, M.S. and Brodie, R.J. (2014), "Consumer brand engagement in social media: conceptualization, scale development and validation”, Journal of Interactive Marketing, Vol. 28 No. 2, pp. 149-165.

Hsu, C., Chiang, Y. and Huang, H. (2012), "How experience-driven community identification generates trust and engagement", Online Information Review, Vol. 36 No. 1, pp. 72-88.

Huang, E. (2012), "Online experiences and virtual goods purchase intention”, Internet Research, Vol. 22 No. 3, pp. 252-274.

Huang, S.-L. and Chen, C.-T. (2018), "How consumers become loyal fans on Facebook", Computers in Human Behavior, Vol. 82, pp. 124-135, available at: www.sciencedirect.com/science/article/pii/S0 747563218300128

Huang, Y.-C., Backman, S.J. and Backman, K.F. (2010), "Student attitude toward virtual learning in second life: a flow theory approach", Journal of Teaching in Travel and Tourism, Vol. 10 No. 4, pp. 312-334.

Internet Live Stats (2017), "Internet users", available at: www.internetlivestats.com/internet-users/ (accessed 14 June 2017).

Jeong, E.-H. (2012), The Application of Imagery to Enhance "Flow State" in Dancers, Victoria University, Melbourne, available at: https://core.ac.uk/download/pdf/10836166.pdf 
Jin, S.-A.A. (2011), “'I feel present. Therefore, I experience flow:' a structural equation modeling approach to flow and presence in video games", Journal of Broadcasting \& Electronic Media, Vol. 55 No. 1, pp. 114-136.

Johnston, L.G. and Sabin, K. (2010), "Sampling hard-to-reach populations with respondent driven sampling”, Methodological Innovations Online, Vol. 5 No. 2, pp. 38-48.

Josiassen, A., Assaf, A.G., Woo, L. and Kock, F. (2016), "The imagery-image duality model: an integrative review and advocating for improved delimitation of concepts", Journal of Travel Research, Vol. 55 No. 6, pp. 789-803.

Kaur, P., Dhir, A. and Rajala, R. (2016), "Assessing flow experience in social networking site based brand communities", Computers in Human Behavior, Vol. 64, pp. 217-225, available at: www. sciencedirect.com/science/article/pii/S0747563216304733

Kaur, P., Dhir, A., Chen, S. and Rajala, R. (2016), "Understanding online regret experience using the theoretical lens of flow experience", Computers in Human Behavior, Vol. 57, pp. 230-239, available at: www.sciencedirect.com/science/article/pii/S0747563215303125

Kim, J. (2011), "Developing an instrument to measure social presence in distance higher education", British Journal of Educational Technology, Vol. 42 No. 5, pp. 763-777.

Kim, J. and Lee, J.-E.R. (2011), "The Facebook paths to happiness: effects of the number of Facebook friends and self-presentation on subjective well-being", Cyberpsychology, Behavior, and Social Networking, Vol. 14 No. 6, pp. 359-364.

Kim, J., Kwon, Y. and Cho, D. (2011), "Investigating factors that influence social presence and learning outcomes in distance higher education", Computers \& Education, Vol. 57 No. 2, pp. 1512-1520.

Klein, L.R. (2003), "Creating virtual product experiences: the role of telepresence”, Journal of Interactive Marketing, Vol. 17 No. 1, pp. 41-55.

Koehn, S., Morris, T. and Watt, A.P. (2013), "Flow state in self-paced and externally-paced performance contexts: an examination of the flow model", Psychology of Sport and Exercise, Vol. 14 No. 6 , pp. 787-795.

Kokkinaki, F. and Lunt, P. (1997), "The relationship between involvement, attitude accessibility and attitude-behaviour consistency", British Journal of Social Psychology, Vol. 36 No. 4, pp. 497-509.

Kuan, G., Morris, T., Kueh, Y.C. and Terry, P.C. (2018), "Effects of relaxing and arousing music during imagery training on dart-throwing performance, physiological arousal indices, and competitive state anxiety", Frontiers in Psychology, Vol. 9 No. 14, pp. 1-12.

Kumar, A. and Kashyap, A.K. (2018), "Leveraging utilitarian perspective of online shopping to motivate online shoppers", International Journal of Retail \& Distribution Management, Vol. 46 No. 3, pp. 247-263.

Kumar, V. and Reinartz, W. (2016), "Creating enduring customer value”, Journal of Marketing, Vol. 80 No. 6, pp. 36-68.

Kwak, K.T., Choi, S.K. and Lee, B.G. (2014), "SNS flow, SNS self-disclosure and post hoc interpersonal relations change: focused on Korean Facebook user", Computers in Human Behavior, Vol. 31 No. 1, pp. 294-304.

Landhäußer, A. and Keller, J. (2012), "Flow and its affective, cognitive, and performance-related consequences", in Engeser, S. (Ed.), Advances in Flow Research, Springer-Verlag, New York, NY, pp. 65-85.

Lee, D., Kim, H.S. and Kim, J.K. (2011), “The impact of online brand community type on consumer's community engagement behaviors: consumer-created vs. marketer-created online brand community in online social-networking web sites", Cyberpsychology, Behavior and Social Networking, Vol. 14 Nos 1-2, pp. 59-63.

Lee, W.-Y., Kwak, D.H., Lim, C., Pedersen, P.M. and Miloch, K.S. (2011), "Effects of personality and gender on fantasy sports game participation: the moderating role of perceived knowledge", Journal of Gambling Studies, Vol. 27 No. 3, pp. 427-441. 
Lemke, F., Clark, M. and Wilson, H. (2010), "Customer experience quality: an exploration in business and consumer contexts using repertory grid technique", Journal of the Academy of Marketing Science, Vol. 39 No. 6, pp. 846-869.

Lemon, K.N. and Verhoef, P.C. (2016), "Understanding customer experience throughout the customer journey”, Journal of Marketing, Vol. 80 No. 6, pp. 69-96.

Leuba, C. (1955), "Toward some integration of learning theories: the concept of optimal stimulation", Psychological Reports, Vol. 1 No. 1, pp. 27-33.

Li, X., Chen, W. and Popiel, P. (2015), "What happens on Facebook stays on Facebook? The implications of Facebook interaction for perceived, receiving, and giving social support", Computers in Human Behavior, Vol. 51, Part A, pp. 106-113, available at: www.sciencedirect. com/science/article/pii/S0747563215003635

Lin, K.-Y. and Lu, H.-P. (2011), "Why people use social networking sites: an empirical study integrating network externalities and motivation theory", Computers in Human Behavior, Vol. 27 No. 3, pp. 1152-1161.

Lin, Y.H., Hsu, C.L., Chen, M.F. and Fang, C.H. (2017), "New gratifications for social word-of-mouth spread via mobile SNSs: uses and gratifications approach with a perspective of media technology", Telematics and Informatics, Vol. 34 No. 4, pp. 382-397.

Liu, H., Chu, H., Huang, Q. and Chen, X. (2016), "Enhancing the flow experience of consumers in China through interpersonal interaction in social commerce", Computers in Human Behavior, Vol. 58, pp. 306-314, available at: www.sciencedirect.com/science/article/pii/S0747563216300127

Liu, X., Schuckert, M. and Law, R. (2018), "Utilitarianism and knowledge growth during status seeking: evidence from text mining of online reviews", Tourism Management, Vol. 66, pp. 38-46, available at: www.sciencedirect.com/science/article/pii/S0261517717302510

Lombard, M. and Ditton, T. (1997), "At the heart of it all: the concept of presence", Journal of ComputerMediated Communication, Vol. 3 No. 2, available at: https:/onlinelibrary.wiley.com/doi/full/10. 1111/j.1083-6101.1997.tb00072.x

Lombard, M. and Jones, M.T. (2015), "Defining presence", in Lombard, M., Biocca, F., Freeman, J., IJsselsteijn, W. and Schaevitz, R.J. (Eds), Immersed in Media: Telepresence Theory, Measurement and Technology, Springer, Cham, pp. 13-34.

López-Bonilla, J.M. and López-Bonilla, L.M. (2008), "Sensation seeking and e-shoppers", Electronic Commerce Research, Vol. 8 No. 3, pp. 143-154.

McDaniel, S.R., Lee, S.C. and Lim, C. (2001), "Re-examining the relationship between fantasy and optimum stimulation levels", Imagination, Cognition and Personality, Vol. 20 No. 4, pp. 355-372.

McLean, G. and Wilson, A. (2016), "Evolving the online customer experience... is there a role for online customer support?", Computers in Human Behavior, Vol. 60, pp. 602-610, available at: www. sciencedirect.com/science/article/pii/S0747563216301479

McQuarrie, E.F. and Munson, J.M. (1992), "A revised product involvement inventory: improved usability and validity”, Advances in Consumer Research, Vol. 19 No. 1, pp. 108-115.

MacInnis, D.J. and Price, L.L. (1987), "The role of imagery in information processing: review and extensions", Journal of Consumer Research, Vol. 13 No. 4, pp. 473-491.

Macrae, C.N., Christian, B.M., Golubickis, M., Karanasiou, M., Troksiarova, L., McNamara, D.L. and Miles, L.K. (2014), "When do I wear me out? Mental simulation and the diminution of self-control", Journal of Experimental Psychology: General, Vol. 143 No. 4, pp. 1755-1764.

Mahatanankoon, P. (2007), "The effects of personality traits and optimum stimulation level on text-messaging activities and m-commerce intention”, International Journal of Electronic Commerce, Vol. 12 No. 1, pp. 7-30.

Makransky, G., Lilleholt, L. and Aaby, A. (2017), "Development and validation of the Multimodal Presence Scale for virtual reality environments: a confirmatory factor analysis and item response theory approach", Computers in Human Behavior, Vol. 72, pp. 276-285, available at: www.sciencedirect.com/science/article/pii/S0747563217301474 
Martínez-López, F.J., Pla-Garcia, C., Gázquez-Abad, J.C. and Rodríguez-Ardura, I. (2014), "Online consumption motivations: an integrated theoretical delimitation and refinement based on qualitative analyses", in Martínez-López, F.J. (Ed.), Handbook of Strategic E-Business Management, Springer, Berlin, pp. 347-370.

Mattie, P. and Munroe-Chandler, K. (2012), "Examining the relationship between mental toughness and imagery use", Journal of Applied Sport Psychology, Vol. 24 No. 2, pp. 144-156.

Medhurst, A.R. and Albrecht, S.L. (2016), "Salesperson work engagement and flow: a qualitative exploration of their antecedents and relationship", Qualitative Research in Organizations and Management: An International Journal, Vol. 11 No. 1, pp. 22-45.

Mennecke, B.E., Triplett, J.L., Hassall, L.M., Jordán Conde, Z. and Heer, R. (2011), “An examination of a theory of embodied social presence in virtual worlds", Decision Sciences, Vol. 42 No. 2, pp. 413-450.

Meyer, C. and Schwager, A. (2007), "Understanding customer experience”, Harvard Business Review, Vol. 85 No. 2, pp. 116-126.

Mollen, A. and Wilson, H. (2010), "Engagement, telepresence and interactivity in online consumer experience: reconciling scholastic and managerial perspectives", Journal of Business Research, Vol. 63 Nos 9-10, pp. 919-925.

Moon, J.-W. and Kim, Y.-G. (2001), "Extending the TAM for a world-wide-web context", Information and Management, Vol. 38 No. 4, pp. 217-230.

Mousa, K., Halaweh, R.S. and Al-Taieb, M.A. (2013), "The effect of movement imagery training on learning forearm pass in volleyball", Education, Vol. 134 No. 2, pp. 227-240.

Munroe, K.J., Giacobbi, P.R. Jr, Hall, C. and Weinberg, R. (2000), “The four Ws of imagery use: where, when, why, and what", Sport Psychologist, Vol. 14 No. 2, pp. 119-137.

Nakamura, J. and Csikszentmihalyi, M. (2009), "Flow theory and research", in Snyder, C.R. and Lopez, S.J. (Eds), Oxford Handbook of Positive Psychology, 2nd ed., Oxford University Press, New York, NY, pp. 195-206.

Naselaris, T., Olman, C.A., Stansbury, D.E., Ugurbil, K. and Gallant, J.L. (2015), “A voxel-wise encoding model for early visual areas decodes mental images of remembered scenes", NeuroImage, Vol. 105, pp. 215-228, available at: www.sciencedirect.com/science/article/pii/S10 53811914008428

Nicholls, A.R., Polman, R.C.J. and Holt, N.L. (2005), "The effects of individualized imagery interventions on golf performance and flow states", Athletic Insight, Vol. 7 No. 1, pp. 43-66.

Novak, T.P., Hoffman, D.L. and Yung, Y.-F. (2000), "Measuring the customer experience in online environments: a structural modeling approach”, Marketing Science, Vol. 19 No. 1, pp. 22-42.

Overmars, S. and Poels, K. (2015), "How product representation shapes virtual experiences and re-patronage intentions: the role of mental imagery processing and experiential value", International Review of Retail, Distribution and Consumer Research, Vol. 25 No. 3, pp. 236-259.

Owloo (2015), "Análisis de España en Facebook", available at: www.owloo.com/facebook-stats/ countries/spain\#_=_ (accessed 26 November 2015).

Pagani, M. and Mirabello, A. (2011), "The influence of personal and social-interactive engagement in social TV web sites", International Journal of Electronic Commerce, Vol. 16 No. 2, pp. 41-67.

Paivio, A. (1985), "Cognitive and motivational functions of imagery in human performance", Canadian Journal of Applied Sport Sciences, Vol. 10 No. 4, pp. 22S-28S.

Park, B., Ahn, S. and Kim, H. (2010), "Blogging: mediating impacts of flow on motivational behavior", Journal of Research in Interactive Marketing, Vol. 4 No. 1, pp. 6-29.

Parra, A. and Argibay, J.C. (2012), "Dissociation, absorption, fantasy proneness and sensation-seeking in psychic claimants", Journal of the Society for Psychical Research, Vol. 76 No. 909, pp. 193-203.

Pates, J., Oliver, R. and Maynard, I. (2001), "Effects of hypnosis on flow states and golf-putting performance", Journal of Applied Sport Psychology, Vol. 13 No. 4, 341-354.

Pearson, J. and Westbrook, F. (2015), "Phantom perception: voluntary and involuntary nonretinal vision”, Trends in Cognitive Sciences, Vol. 19 No. 5, pp. 278-284. 
Pearson, J., Naselaris, T., Holmes, E.A. and Kosslyn, S.M. (2015), "Mental imagery: functional mechanisms and clinical applications”, Trends in Cognitive Sciences, Vol. 19 No. 10, pp. 590-602.

Pelet, J.-É., Ettis, S. and Cowart, K. (2017), "Optimal experience of flow enhanced by telepresence: evidence from social media use", Information and Management, Vol. 54 No. 1, pp. 115-128.

Petermans, A., Janssens, W. and van Cleempoel, K. (2013), "A holistic framework for conceptualizing customer experiences in retail environments”, International Journal of Design, Vol. 7 No. 2, pp. 1-18.

Petty, R.E. and Cacioppo, J.T. (1981), "Issue involvement as a moderator of the effects on attitude of advertising content and context", Advances in Consumer Research, Vol. 8 No. 1, pp. 20-24.

Petty, R.E. and Cacioppo, J.T. (1986), Communication and Persuasion: Central and Peripheral Routes to Attitude Change, Springer-Verlag, New York, NY.

Petty, R.E. and Cacioppo, J.T. (1990), "Involvement and persuasion: tradition versus integration", Psychological Bulletin, Vol. 107 No. 3, pp. 367-374.

Petty, R.E., Cacioppo, J.T. and Schumann, D. (1983), "Central and peripheral routes to advertising effectiveness: the moderating role of involvement", Journal of Consumer Research, Vol. 10 No. 2, pp. 135-146.

Pierro, A., Mannetti, L., Kruglanski, A.W., Klein, K. and Orehek, E. (2012), "Persistence of attitude change and attitude-behavior correspondence based on extensive processing of source information”, European Journal of Social Psychology, Vol. 42 No. 1, pp. 103-111.

Pillai, J.S., Schmidt, C. and Richir, S. (2013), “Achieving presence through evoked reality”, Frontiers in Psychology, Vol. 4 No. 86, pp. 1-13.

Piyathasanan, B., Mathies, C., Wetzels, M., Patterson, P.G. and de Ruyter, K. (2014), "A hierarchical model of virtual experience and its influences on the perceived value and loyalty of customers", International Journal of Electronic Commerce, Vol. 19 No. 2, pp. 126-158.

Pizam, A., Jeong, G.-H., Reichel, A., van Boemmel, H., Lusson, J.M., Steynberg, L., State-Costache, O., Volo, S., Kroesbacher, C., Kucerova, J. and Montmany, N. (2004), "The relationship between risktaking, sensation-seeking, and the tourist behavior of young adults: a cross-cultural study", Journal of Travel Research, Vol. 42 No. 3, pp. 251-260.

Plummer, J., Cook, B., Diforio, D., Schachter, B., Sokolyanskaya, I. and Korde, T. (2007), Measures of Engagement, Vol. II, Advertising Research Foundation, New York, NY.

Potdar, V., Joshi, S., Harish, R., Baskerville, R. and Wongthongtham, P. (2018), "A process model for identifying online customer engagement patterns on Facebook brand pages", Information Technology \& People, Vol. 31 No. 2, pp. 595-614.

Pöyry, E., Parvinen, P. and Malmivaara, T. (2013), "Can we get from liking to buying? Behavioral differences in hedonic and utilitarian Facebook usage", Electronic Commerce Research and Applications, Vol. 12 No. 4, pp. 224-235.

Raju, P.S. (1980), "Optimum stimulation level: its relationship to personality, demographics, and exploratory behavior", Journal of Consumer Research, Vol. 7 No. 3, pp. 272-283.

Richard, M.-O. and Chandra, R. (2005), "A model of consumer web navigational behavior: conceptual development and application", Journal of Business Research, Vol. 58 No. 8, pp. 1019-1029.

Richard, M.-O. and Chebat, J.-C. (2016), "Modeling online consumer behavior: preeminence of emotions and moderating influences of need for cognition and optimal stimulation level", Journal of Business Research, Vol. 69 No. 2, pp. 541-553.

Rodríguez-Ardura, I. and Martínez-López, F.J. (2014), “Another look at 'being there' experiences in digital media: exploring connections of telepresence with mental imagery", Computers in Human Behavior, Vol. 30 No. 1, pp. 508-518.

Rodríguez-Ardura, I. and Meseguer-Artola, A. (2016), "E-learning continuance: the impact of interactivity and the mediating role of imagery, presence and flow", Information and Management, Vol. 53 No. 4, pp. 504-516.

Rodríguez-Ardura, I. and Meseguer-Artola, A. (2017), "Flow in e-learning: what drives it and why it matters", British Journal of Educational Technology, Vol. 48 No. 4, pp. 899-915. 
Rodríguez-Ardura, I., Meseguer-Artola, A. (2018), "The playfulness of Facebook - Shaped by underlying psychological drivers and gender differences", Telematics and Informatics (in press), doi: 10.1016/J.TELE.2018.09.004.

Rodríguez-Ardura, I., Meseguer-Artola, A. and Ammetller, G. (2016), "How do the experiences of virtual presence and flow differ? Evidence from Engineering and ICT online education", International Journal of Engineering Education, Vol. 32 No. 4, pp. 1579-1585.

Rose, S., Clark, M., Samouel, P. and Hair, N. (2012), "Online customer experience in e-retailing: an empirical model of antecedents and outcomes", Journal of Retailing, Vol. 88 No. 2, pp. 308-322.

Imagine, feel

"there", and flow!

SanJosé-Cabezudo, R., Gutiérrez-Arranz, A.M. and Gutiérrez-Cillán, J. (2009), "The combined influence of central and peripheral routes in the online persuasion process", CyberPsychology \& Behavior, Vol. 12 No. 3, pp. 299-308.

Sanz-Blas, S., Bigné, E. and Buzova, D. (2017), "m-WOM in a brand's Facebook fan page", Online Information Review, Vol. 41 No. 7, pp. 936-953.

Sarstedt, M., Henseler, J. and Ringle, C.M. (2011), "Multigroup analysis in partial least squares (PLS) path modeling: alternative methods and empirical results", in Sarstedt, M., Schwaiger, M. and Taylor, C.R. (Eds), Measurement and Research Methods in International Marketing (Advances in International Marketing), Vol. 22, Emerald Group Publishing Limited, pp. 195-218, available at: http://dx.doi.org/10.1108/S1474-7979(2011)0000022012

Sas, C. and O'Hare, G.M.P. (2003), "Presence equation: an investigation into cognitive factors underlying presence", Presence, Vol. 12 No. 5, pp. 523-537.

Sashittal, H.C., Sriramachandramurthy, R. and Hodis, M. (2012), "Targeting college students on Facebook? How to stop wasting your money”, Business Horizons, Vol. 55 No. 5, pp. 495-507.

Saunders, C., Rutkowski, A.F., von Genuchten, M., Vogel, D. and Orrego, J.M. (2011), "Virtual space and place: theory and test”, MIS Quarterly, Vol. 35 No. 4, pp. 1079-1098.

Schubert, T., Friedmann, F. and Regenbrecht, H. (2001), "The experience of presence: factor analytic insights", Presence, Vol. 10 No. 3, pp. 266-281.

Schubert, T.W. (2009), "A new conception of spatial presence: once again, with feeling", Communication Theory, Vol. 19 No. 2, pp. 161-187.

Schulze, C., Schöler, L. and Skiera, B. (2014), "Not all fun and games: viral marketing for utilitarian products", Journal of Marketing, Vol. 78 No. 1, pp. 1-19.

Seo, M., Kim, J. and Yang, H. (2016), "Frequent interaction and fast feedback predict perceived social support: using crawled and self-reported data of Facebook users", Journal of Computer-Mediated Communication, Vol. 21 No. 4, pp. 282-297.

Shim, S.I., Forsythe, S. and Kwon, W.-S. (2015), "Impact of online flow on brand experience and loyalty", Journal of Electronic Commerce Research, Vol. 16 No. 1, pp. 56-71.

Shin, D. (2018), "Empathy and embodied experience in virtual environment: to what extent can virtual reality stimulate empathy and embodied experience?", Computers in Human Behavior, Vol. 78, pp. 64-73, available at: www.sciencedirect.com/science/article/pii/S0747563217305381

Shin, D. and Biocca, F. (2018), "Exploring immersive experience in journalism”, New Media and Society, Vol. 20 No. 8, pp. 2800-2823.

Slagter, H.A., Davidson, R.J. and Lutz, A. (2011), "Mental training as a tool in the neuroscientific study of brain and cognitive plasticity", Frontiers in Human Neuroscience, Vol. 5 No. 17, pp. 1-12.

Slater, M., Usoh, M. and Steed, A. (1994), "Depth of presence in virtual environments", Presence: Teleoperators and Virtual Environments, Vol. 3 No. 2, pp. 130-144.

So, K.K.F., King, C. and Sparks, B. (2014), "Customer engagement with tourism brands: scale development and validation", Journal of Hospitality and Tourism Research, Vol. 38 No. 3, pp. 304-329.

So, K.K.F., King, C., Sparks, B.A. and Wang, Y. (2016), "The role of customer engagement in building consumer loyalty to tourism brands", Journal of Travel Research, Vol. 55 No. 1, pp. 64-78. 
Spector, P.E., Cooper, C.L. and Sparks, K. (2001), "An international study of the psychometric properties of the Hofstede values survey module 1994: a comparison of individual and country/ province level results", Applied Psychology, Vol. 50 No. 2, pp. 269-281.

Steenkamp, J.-B.E.M. and Baumgartner, H. (1992), "The role of optimum stimulation level in exploratory consumer behavior", Journal of Consumer Research, Vol. 19 No. 3, pp. 434-448.

Steenkamp, J.-B.E.M. and Baumgartner, H. (1995), "Development and cross-cultural validation of a short form of CSI as a measure of optimum stimulation level", International Journal of Research in Marketing, Vol. 12 No. 2, pp. 97-104.

Steenkamp, J.-B.E.M. and Burgess, S.M. (2002), "Optimum stimulation level and exploratory consumer behavior in an emerging consumer market", International Journal of Research in Marketing, Vol. 19 No. 2, pp. 131-150.

Truong, Y., McColl, R. and Kitchen, P. (2010), "Practitioners' perceptions of advertising strategies for digital media", International Journal of Advertising, Vol. 29 No. 5, pp. 709-725.

van Doorn, J., Lemon, K.N., Mittal, V., Nass, S., Pick, D., Pirner, P. and Verhoef, P.C. (2010), "Customer engagement behavior: theoretical foundations and research directions", Journal of Service Research, Vol. 13 No. 3, pp. 253-266.

Vargo, S.L. and Lusch, R.F. (2004), "Evolving to a new dominant logic for marketing", Journal of Marketing, Vol. 68 No. 1, pp. 1-17.

Vargo, S.L. and Lusch, R.F. (2016), "Institutions and axioms: an extension and update of service-dominant logic", Journal of the Academy of Marketing Science, Vol. 44 No. 1, pp. 5-23.

Vernuccio, M. and Ceccotti, F. (2015), "Strategic and organisational challenges in the integrated marketing communication paradigm shift: a holistic vision", European Management Journal, Vol. 33 No. 6, pp. 438-449.

Vonkeman, C., Verhagen, T. and van Dolen, W. (2017), "Role of local presence in online impulse buying", Information and Management, Vol. 54 No. 8, pp. 1038-1048.

Walters, G., Sparks, B. and Herington, C. (2012), "The impact of consumption vision and emotion on the tourism consumer's decision behavior", Journal of Hospitality \& Tourism Research, Vol. 36 No. 3, pp. 366-389.

Wang, T., Duong, T.D. and Chen, C.C. (2016), "Intention to disclose personal information via mobile applications: a privacy calculus perspective", International Journal of Information Management, Vol. 36 No. 4, pp. 531-542.

Wirth, W., Hartmann, T., Böcking, S., Vorderer, P., Klimmt, C., Schramm, H., Saari, T., Laarni, J., Ravaja, N., Gouveia, F.R., Biocca, F., Sacau, A., Jäncke, L., Baumgartner, T. and Jäncke, P. (2007), "A process model of the formation of spatial presence experiences", Media Psychology, Vol. 9 No. 3, pp. 493-525.

Woszczynski, A.B., Roth, P.L. and Segars, A.H. (2002), "Exploring the theoretical foundations of playfulness in computer interactions", Computers in Human Behavior, Vol. 18 No. 4, pp. 369-388.

Wu, J. and Holsapple, C. (2014), "Imaginal and emotional experiences in pleasure-oriented IT usage: a hedonic consumption perspective", Information and Management, Vol. 51 No. 1, pp. 80-92.

Yang, H.-L. and Lin, C.-L. (2014), "Why do people stick to Facebook web site? A value theory-based view”, Information Technology \& People, Vol. 27 No. 1, pp. 21-37.

Yuille, J.C. and Catchpole, M.J. (1977), "The role of imagery in models of cognition”, Journal of Mental Imagery, Vol. 1 No. 1, pp. 171-180.

Zheng, X., Cheung, C.M.K., Lee, M.K.O. and Liang, L. (2015), "Building brand loyalty through user engagement in online brand communities in social networking sites", Information Technology \& People, Vol. 28 No. 1, pp. 90-106.

Zuckerman, M. (1979), Sensation Seeking: Beyond the Optimal Level of Arousal, Erlbaum, Hillsdale, NJ. 


\section{About the authors}

Dr Inma Rodríguez-Ardura is Associate Professor of Marketing and Director of the Digital Business Research Group at the Open University of Catalonia (Universitat Oberta de Catalunya), as well as a part-time Lecturer at the University of Miami. She has served at the University of Oxford, and at Babson College (Boston), as a visiting professor. Her latest papers have appeared in British Journal of Educational Technology, Computers \& Education, Electronic Commerce Research and Applications, IEEE Transactions on Professional Communication, Information and Management, Information Society, Interactive Learning Environments, and Internet Research. Her research interests gravitate towards digital marketing and online user experience. Dr Inma Rodríguez-Ardura is the corresponding author and can be contacted at: irodriguez@uoc.edu

Dr Antoni Meseguer-Artola is Associate Professor of Quantitative Methods and Researcher of the Digital Business Research Group at the Open University of Catalonia (Universitat Oberta de Catalunya). He has produced a number of articles, conference papers and handbooks. His current research focuses on users' behaviour in immersive virtual environments and online education.
Imagine, feel

"there", and flow!

For instructions on how to order reprints of this article, please visit our website: 